\title{
Challenges in Anaesthesia of Children with Autistic Spectrum Disorders
}

\author{
K. Tsvetanova ${ }^{1}$, S. Tsvetkova ${ }^{2}$, M. Atanasova ${ }^{3}$, E. Odiseeva ${ }^{4}$ \\ ${ }^{1}$ UMHAT “Dr. G.Stranski” Ltd.-city of Pleven, Clinic in Anaesthesiology and Intensive Care \\ ${ }^{2}$ Medical University - city of Pleven- Faculty "Public Health" \\ ${ }^{3}$ UMHAT "Sveta Anna"-city of Sofia ${ }^{3}$
}

${ }^{4}$ High Medical Academy -city of Sofia- Clinic in Anaesthesiology and Intensive Care ${ }^{4}$

\begin{abstract}
Autism is a disease of the brain. It affects 6 in every 1000 children from all races, ethnical and social groups. Most of the physicians say it is more of a condition, rather than a disease. Children who suffer from autism have problems with communication and lack social skills. This is why they have to be under anesthesia when various medical manipulations or operations are performed. Prior to all those interventions are necessary not only consultations with pediatrician, anesthesiologists and other specialists but also close collaboration with psychologists who know the specific character of this condition.
\end{abstract}

Keywords: autism, preoperative preparation, anesthesia

\section{Introduction}

Autism is a most general brain disorder. It affects 6 in every 1000 children from all races, ethnical and social groups. With the exception of syndrome of Rett, all its types are encountered 3 to 4 times more frequently with boys rather than with girls. Most doctors define it as a condition rather than a disease. Autistic children have problems with communication and social relations. They can have as well atypical: manner of behavior, interests and movements.

Autism is a comparatively rare disorder but in the last years globally there has been reported a statistical increase in the autistic disorder cases. During the last twenty years in Bulgaria the diagnose set-up passes from interference phase (delay in the nerve and psychic development) to the proper diagnosis. Despite this achievement there is still more to be done in direction of the early diagnostics. Frequently parents have stress by the fact that their child does not comply with the regularities pertaining to the development of other children of same age and they look for information from casual sources [1]. They are confused, anxious, feeling guilt and having many questions and few answers.

\section{Etiology}

For syndrome of Rett is typical that it appears as a result of genetic mutation. For the other types of autism reasons remain unclear despite the numerous studies. Some scientists consider that infection or environmental toxin are reasons for this disease. Others accept that autism could be displayed at brain trauma or brain disorder during the intrauterine development or during the early childhood.

Third group of researchers considers that this disease is a result of atypical levels of chemical compounds (neurotransmitters) like dopamine and serotonin that transfer the nerve signals between the cells [2].
In International Disease Codes $\mathrm{X}$ are described the following types of autism, and three of them are the most frequent:

1) Classic autism;

2) Syndrome of Asperger - lighter type of disease;

3) PDD- ( Not Otherwise Specified) - used to describe the group of children who do not fit in the other types of autism.

Two types of this disease are encountered less frequently:

4) Syndrome of Rett - neurological disorder that appears in girls. It includes problems with movement and speech together with the remaining symptoms typical for autism.

5) Child's disintegrating disorder. This is the most severe type of this disease when child looses more physical, linguistic and social skills than in the other types.

Interpretation of autism as a generalized developmental disorder and a trinity of social, behavioral and communicative disorders in DSM III is preserved in DSM IV but in another vision - the generalized developmental disorders are being considered as particular conditions [3].

- Syndrome of Asperger - deterioration of social interaction, routine and repetitive behavioral models and activity. There is no development of personal selfimprovement habits corresponding to certain age, no adaptive behavior and the specific curiosity of childhood; there is no spontaneous sharing of pleasures. In the same time the manifestation of stubborn interest in parts and details of certain objects is typical. Formation of basic movements comes later, motion affectation and adherence to ritual activities are displayed.

- Syndrome of Rett /mainly in children of female sex/ - a characteristic feature is the delayed development of physical parameter finger growth between 5 and 48 months. Mastered purposeful hand habits are lost or there appear strange hand movements reminding handwashing and twisting of fingers. Dynamic coordination is disturbed. During the pre-school period, difficulties in social functioning are observed. 


\section{International Journal of Science and Research (IJSR) \\ ISSN (Online): 2319-7064}

Index Copernicus Value (2013): 6.14 | Impact Factor (2015): 6.391

- Atypical autism/designated as unspecific generalized development disorder/ - it can be diagnosed when the child's activities are less than the activities in syndrome of
L.Kanner. Table 1 shows in comparative aspect the different symptoms between syndrome of L. Kanner and syndrome of Asperger. [Table 1]

Table 1: Comparison between syndrome of L.Kanner and syndrome of Asperger [4]

\begin{tabular}{|c|c|}
\hline & $\begin{array}{c}\text { SYNDROME OF ASPERGER } \\
\end{array}$ \\
\hline $\begin{array}{l}\text { Manifests itself exclusively with boys. } \\
\text { Manifests itself during the first year of life. } \\
\text { - Walking develops earlier than speech. } \\
\text { There is no visual contact, others are not noticed. } \\
\text { - Speech does not perform communicative functions. } \\
\text { Problems in cognitive sphere. } \\
\text { Limited intellectual activities. } \\
\text { Restless behavior, frequently accompanied by } \\
\text { extreme affect reactions. } \\
\text { When hospitalized there is indifference towards the } \\
\text { new setting. }\end{array}$ & $\begin{array}{l}\text { - Manifests itself with boys as wells as with girls } \\
\text {. } \\
\text { life. } \\
\text {. } \quad \text { Speech appears before walking. } \\
\text { Visual contact is fugitive, shallow } \\
\text {. } \quad \text { Speech is with communicative functions. } \\
\text {. } \quad \text { Intellectual development is within the limits of norm. } \\
\text {. } \quad \text { Strange behavior. } \\
\text { - When hospitalized there is desire to return back home, } \\
\text { but also indifference to the missing relatives. }\end{array}$ \\
\hline
\end{tabular}

In literature were defined the basic manifestations of autistic disorder [3]:

a) Qualitative disorders in social integration noticed in: - missing or limited abilities of inter-personal perception;

- missing or abnormal requirements for comfort at distress situation;

- missing or disturbed imitation;

- missing or abnormal social game;

- considerable disturbances in the abilities to build up friendly relations

b) Qualitative disorders in verbal and non-verbal communication as well as in creative work:

- There are no communication instruments like facial expression, mimics, gesticulation or in spoken language;

- There are abnormal models for non-verbal communication not using eye contact or body position;

- Lack of creative activities such as playing the role of adults, image-fantasies or images of animals, lack of interest towards fairy tales;

- Disturbances in speech production, such as content, rhythm, intonation, strength and pitch;

- Speech forms and content are disturbed;

- Disturbed abilities to begin or maintain conversation.

c) Presence of repeating activities and interests demonstrated in:

- Stereotypical body movements such as complex body movements, monotonous shaking of one's head;

- Persistent interest in parts of different objects;
- Distress demonstration when trivial aspects of surrounding media have been changed;

- Misunderstanding of changeable punctually defined details and change;

- Interest only in one way.

Autistic children demonstrate no or slight interest towards the others including towards the members of their family [5]. There is no motivation for social integration. The deficit in linguistic and speech development appears to be a clear indicator. Most of the autistic children are non-verbal. They either establish elementary communicative acts with prevailing non-verbal and scanty usage of signs or demonstrate echolalia, perceiverations or usage of words that are not included in the standards of any language [4].

Definitive for the differential diagnostics is the so called trinity of social interaction: disturbance of social interrelations, disturbance of social communication and disturbance of social understanding and presentation [4], [7].

Specific monitoring features could be: lack of any selfdefense reactions, fear (from height, animals, darkness ect.), unspecific reactions of pain ( its location is not pointed out, pain is not expressed in habitual way, its intensity is not well defined etc). Due to the behavioral disorders autistic children react in atypical mode to stomachache, and frequently it is not "decoded" by their parents [8]. In general, Table 2 presents five cases from personal practices, which have been consulted in the period $2010-2015$. [Table 2]

Table 2: Cases from personal practices, which have been consulted in the period $2010-2015$

\begin{tabular}{|c|c|c|c|c|c|c|}
\hline $\begin{array}{c}\text { Group } \\
\text { of } \\
\text { indicators }\end{array}$ & Indicators & $\begin{array}{c}\text { I.M.V. - boy, } 5 \\
\text { yrs. } 3 \mathrm{~m} .\end{array}$ & $\begin{array}{c}\text { E.T.P. }- \text { girl, } 4 \\
\text { yrs. }\end{array}$ & $\begin{array}{l}\text { A.N.N. -boy, } \\
6 \text { yrs. } 7 \mathrm{~m} .\end{array}$ & $\begin{array}{c}\text { A.S.M. -girl, } 5 \\
\text { yrs. }\end{array}$ & $\begin{array}{c}\text { S.T.S. }- \text { boy, } 3 \text { yrs. } \\
5 \mathrm{~m} .\end{array}$ \\
\hline 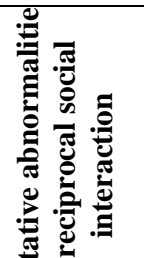 & $\begin{array}{l}\text { Disability to use eye } \\
\text { contact, body position, } \\
\text { facial expres sion and } \\
\text { gestu res for adequate } \\
\text { interaction regulation. }\end{array}$ & $\begin{array}{c}\text { Lack of visual } \\
\text { contact,stereo } \\
\text { type body } \\
\text { movements. Does } \\
\text { not use gestures to } \\
\text { state a certain } \\
\text { need. }\end{array}$ & $\begin{array}{c}\text { Lack of visual } \\
\text { contact. Hyper } \\
\text { active. Not well } \\
\text { coordina } \\
\text { ted. Destruc tive } \\
\text { towards material } \\
\text { objects. }\end{array}$ & $\begin{array}{l}\text { Lack of visual } \\
\text { con tact, stereo } \\
\text { typic hand } \\
\text { movements. In } \\
\text { some moments } \\
\text { is chaotic. }\end{array}$ & $\begin{array}{c}\text { Slight visual } \\
\text { contact. Changes } \\
\text { her expression } \\
\text { spontaneously. } \\
\text { Impulsive. }\end{array}$ & $\begin{array}{c}\text { Lack of visual } \\
\text { contact. Not well } \\
\text { coordinated when } \\
\text { walking. Does not } \\
\text { feed himself. }\end{array}$ \\
\hline 氕 & $\begin{array}{c}\text { Lack of development } \\
\text { corresponding to mental }\end{array}$ & $\begin{array}{l}\text { Lack of cognitive } \\
\text { interest. Attention }\end{array}$ & $\begin{array}{l}\text { Specificity of } \\
\text { development. }\end{array}$ & $\begin{array}{c}\text { Can be } \\
\text { monitored. }\end{array}$ & $\begin{array}{c}\text { Moderate } \\
\text { mentally }\end{array}$ & $\begin{array}{l}\text { Does not interacts } \\
\text { with children of the }\end{array}$ \\
\hline
\end{tabular}




\section{International Journal of Science and Research (IJSR) \\ ISSN (Online): 2319-7064}

Index Copernicus Value (2013): 6.14 | Impact Factor (2015): 6.391

\begin{tabular}{|c|c|c|c|c|c|c|}
\hline & $\begin{array}{l}\text { age and despite of the } \\
\text { existing possibilities, of } \\
\text { relations with children } \\
\text { of the same age, inclu- } \\
\text { ding common interests, } \\
\text { attitu-des and emoti- } \\
\text { ons, }\end{array}$ & $\begin{array}{c}\text { is of no deliberate } \\
\text { nature. Neces-sity } \\
\text { of comm.- } \\
\text { unication with } \\
\text { others is not } \\
\text { monitored. }\end{array}$ & \begin{tabular}{|} 
Recognizes \\
colors, has some \\
concepts already \\
shaped. \\
Sporadically \\
establishes contact \\
with other adult. \\
There is a need of \\
stimulus material.
\end{tabular} & $\begin{array}{c}\text { After mother's } \\
\text { data, the boy } \\
\text { can play pia- no. } \\
\text { Has a specific } \\
\text { me-mory for } \\
\text { movements' } \\
\text { sequence. }\end{array}$ & $\begin{array}{l}\text { retarded. Well } \\
\text { influenced by } \\
\text { specialized } \\
\text { complex care. } \\
\text { Interacts with } \\
\text { other children. }\end{array}$ & same age or adults. \\
\hline & $\begin{array}{l}\text { Rarely looks for or uses } \\
\text { other people. }\end{array}$ & $\begin{array}{c}\text { Does not seek his } \\
\text { parents and other } \\
\text { people. }\end{array}$ & $\begin{array}{c}\text { Does not seek her } \\
\text { parents and other } \\
\text { people. }\end{array}$ & $\begin{array}{c}\text { Partially. } \\
\text { Attached to his } \\
\text { mother. }\end{array}$ & $\begin{array}{l}\text { Has emotional } \\
\text { contact with the } \\
\text { mother. }\end{array}$ & $\begin{array}{l}\text { Does not seek his } \\
\text { parents and other } \\
\text { people. }\end{array}$ \\
\hline & Lack of sharing & $\begin{array}{c}\text { It is present. Non- } \\
\text { verbal. }\end{array}$ & It is present. & It is present. & It is present. & It is present. \\
\hline & $\begin{array}{l}\text { Lack of social- } \\
\text { emotional reciprocity. }\end{array}$ & $\begin{array}{c}\text { It is present. } \\
\text { Emotional deficit. } \\
\text { Not attached. }\end{array}$ & $\begin{array}{c}\text { It is present. } \\
\text { Emotional deficit. } \\
\text { Slight emotional } \\
\text { attachment. }\end{array}$ & It is present. & $\begin{array}{l}\text { Partially. Inclined } \\
\text { to aggression and } \\
\text { autoagression. }\end{array}$ & It is present. \\
\hline \multirow{5}{*}{ 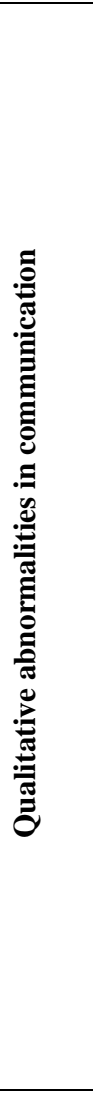 } & $\begin{array}{l}\text { Retarded or total lack of } \\
\text { speech which is not } \\
\text { compensated by the } \\
\text { usage of gestures or } \\
\text { mimics. }\end{array}$ & $\begin{array}{c}\text { Lack of linguistic } \\
\text { structures. }\end{array}$ & \begin{tabular}{|c|} 
Does use the \\
mastered \\
words(from the \\
spoken language) \\
to declare a need \\
and for a contact. \\
\end{tabular} & $\begin{array}{l}\text { Falls behind in } \\
\text { the lingu-istic } \\
\text { deve-lopment. } \\
\text { Does not use } \\
\text { gestures or } \\
\text { mimics. }\end{array}$ & $\begin{array}{l}\text { Speech is scanty, } \\
\text { strongly } \\
\text { restricted. } \\
\text { Notdeliberate. } \\
\text { Rarely it is a } \\
\text { situational one. } \\
\end{array}$ & $\begin{array}{l}\text { Falls behind is the } \\
\text { linguistic } \\
\text { development. }\end{array}$ \\
\hline & $\begin{array}{c}\text { Relative difficulty to } \\
\text { begin or maintain a } \\
\text { conversation. }\end{array}$ & $\begin{array}{l}\text { Expressed } \\
\text { difficulty. }\end{array}$ & It is present. & & It is present. & It is present. \\
\hline & $\begin{array}{l}\text { Stereotypic and } \\
\text { repeated usage of } \\
\text { language and/ } \\
\text { or idiopathic use of } \\
\text { words and phrases. }\end{array}$ & $\begin{array}{l}\text { It is not } \\
\text { monitored. }\end{array}$ & \begin{tabular}{|c|} 
Synthetic, \\
idiopathic, \\
emotionally \\
saturated \\
"language". Not \\
determined \\
laughter. \\
\end{tabular} & Sometimes. & $\begin{array}{l}\text { It is monitored. } \\
\text { Echolalolic } \\
\text { speech. }\end{array}$ & $\begin{array}{c}\text { Stereotypic } \\
\text { repetitions of } \\
\text { phrases without any } \\
\text { content. }\end{array}$ \\
\hline & $\begin{array}{l}\text { Abnormality in the } \\
\text { pitch, stress, pace, } \\
\text { rhythm and intonation } \\
\text { of the voice. }\end{array}$ & Not monitored. & $\begin{array}{c}\text { Clear diction, } \\
\text { good intonation. } \\
\text { She has musical } \\
\text { ear. Infringements } \\
\text { in the pace. }\end{array}$ & \begin{tabular}{|} 
When speaking \\
a change in \\
rhythm can be \\
noticed \\
periodically. \\
Especially in the \\
chaotic \\
movements.
\end{tabular} & It is monitored. & Not monitored. \\
\hline & $\begin{array}{l}\text { Lack of spontaneous } \\
\text { game and socially } \\
\text { imitative game. }\end{array}$ & $\begin{array}{l}\text { It is present. } \\
\text { Manipulation with } \\
\text { toys is not } \\
\text { considered as a } \\
\text { game act. }\end{array}$ & $\begin{array}{c}\text { Impulsive } \\
\text { displays of a } \\
\text { desire for } \\
\text { dynamic game, } \\
\text { freque-ntly she is } \\
\text { not cooperative. }\end{array}$ & & $\begin{array}{l}\text { Sometimes there } \\
\text { is a desire for } \\
\text { game interaction } \\
\text { with the others. }\end{array}$ & It is present. \\
\hline \multirow{6}{*}{ 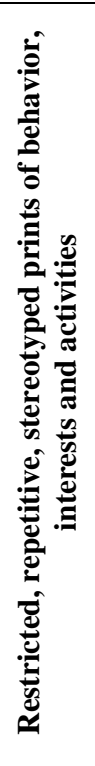 } & $\begin{array}{l}\text { Overwhelming } \\
\text { meditation in } \\
\text { stereotypic and } \\
\text { restricted interests. } \\
\end{array}$ & $\begin{array}{c}\text { Partially. } \\
\text { Attracted by } \\
\text { centrifugation in } \\
\text { washing machine. }\end{array}$ & It is present. & Partially. & Partially. & $\begin{array}{c}\text { When aligning } \\
\text { objects on the table } \\
\text { he shows pedantry. }\end{array}$ \\
\hline & $\begin{array}{c}\text { Specific attachment to } \\
\text { unusual objects. }\end{array}$ & $\begin{array}{c}\text { It is not } \\
\text { monitored. }\end{array}$ & $\begin{array}{l}\text { It is not } \\
\text { monitored. }\end{array}$ & $\begin{array}{l}\text { To cosmetic } \\
\text { catalogues. }\end{array}$ & To a toy. & To clothes-pins. \\
\hline & $\begin{array}{c}\text { Noticeable } \\
\text { attachment/clinging/ to } \\
\text { specific non-functional } \\
\text { rituals. }\end{array}$ & $\begin{array}{l}\text { It is being } \\
\text { registered-sand, } \\
\text { water, foam. }\end{array}$ & $\begin{array}{l}\text { It is not } \\
\text { monitored. }\end{array}$ & $\begin{array}{c}\text { To opening and } \\
\text { closing of door, } \\
\text { cabinet, } \\
\text { wardrobe. } \\
\text { Cables. } \\
\end{array}$ & $\begin{array}{c}\text { To food. } \\
\text { External control is } \\
\text { needed daily. }\end{array}$ & $\begin{array}{l}\text { Unfastening of } \\
\text { press studs, } \\
\text { magnets. }\end{array}$ \\
\hline & $\begin{array}{l}\text { Stereotypic and } \\
\text { repeated motor } \\
\text { mannerisms }\end{array}$ & $\begin{array}{c}\text { They are } \\
\text { monitored during } \\
\text { most of the time. }\end{array}$ & $\begin{array}{c}\text { They are } \\
\text { monitored } \\
\text { periodically. }\end{array}$ & $\begin{array}{c}\text { They are } \\
\text { monitored. } \\
\text { All the time the } \\
\text { mother stands } \\
\text { next to him. } \\
\end{array}$ & $\begin{array}{l}\text { Sometimes. } \\
\text { She turns in } \\
\text { circle. }\end{array}$ & $\begin{array}{l}\text { When an external } \\
\text { person comes in, he } \\
\text { immediately glues } \\
\text { in a corner. }\end{array}$ \\
\hline & $\begin{array}{c}\text { Meditation in sections } \\
\text { or nonfunctional } \\
\text { characteristics of the } \\
\text { objects. }\end{array}$ & $\begin{array}{l}\text { When interacting } \\
\text { with sand, water, } \\
\text { foam. }\end{array}$ & $\begin{array}{c}\text { It is present. } \\
\text { Not monitored all } \\
\text { the time. }\end{array}$ & Sometimes. & \multirow[t]{2}{*}{$\begin{array}{c}\text { Slightly } \\
\text { expressed. }\end{array}$} & $\begin{array}{l}\text { Arranging of } \\
\text { objects. }\end{array}$ \\
\hline & Distress when tiny, & It is monitored. & Slight, negative & Aggravates the & & He gets upset when \\
\hline
\end{tabular}




\section{International Journal of Science and Research (IJSR) \\ ISSN (Online): 2319-7064}

Index Copernicus Value (2013): 6.14 | Impact Factor (2015): 6.391

\begin{tabular}{|c|c|c|c|c|c|c|}
\hline $\begin{array}{c}\text { non-funct-ional details } \\
\text { in the media are } \\
\text { changed. }\end{array}$ & $\begin{array}{c}\text { Becomes worried, } \\
\text { becomes affected } \\
\text { quickly. }\end{array}$ & $\begin{array}{c}\text { emotional } \\
\text { transitions. }\end{array}$ & $\begin{array}{c}\text { chaotic, } \\
\text { behavioral } \\
\text { models. He has } \\
\text { a good memory } \\
\text { for locations } \\
\text { and routes. }\end{array}$ & $\begin{array}{c}\text { Strong emotional } \\
\text { reaction when the } \\
\text { setting is being } \\
\text { changed. }\end{array}$ & $\begin{array}{c}\text { there are changes in } \\
\text { the setting. }\end{array}$ & \\
\hline
\end{tabular}

Along with the fast increase of cases from autistic spectrum diseases (ASD) and the extension of debate for best treatment and therapy, the consequences for family life from a ASD diagnosis remain comparatively unstudied. In many cases the opinions of parents and professionals do not always coin-cide [9].

Anaesthesia and ASD: At early childhood age children with autism frequently need several unpleasant medical tests or procedures to be performed and this imposes the implementation of sedation or anaesthesia. This poses in front of anaesthesiologist several challenges due to the specific nature of this disease.

Pre-operative preparation: Most frequently the problems connected with pre-operative preparation of autistic children are bind with:

1) Difficulties to establish contact with them and impossibility for them to describe their complains.

2) Lack of desire to establish physical contact.

3) They are uncooperative when some functional tests are done (nuclear magnetic resonance/NMR/, functional lung tests etc.)

4) Frequently they feel fear when enter unfamiliar surrounding.

The nature of this disease suggests difficult communication with the children. Frequently they have heightened anxiety, wary attitude, and sometimes they are aggressive. That is why the aneasthesiologist who should implement the anaesthesia has to apply different than the usual methods in order to gather information for these children.

This is done through a preliminary conversation with the parents (the child's guardian) about the child's physical and psychological needs. Rainey L(1998) recommends the preoperative preparation for anaesthesia to include obligatory a talk with parents dealing with the work schedule of the anaesthesia and the possible options for its implementation[10]. Sometimes for the child's comfort it is necessary to bring in the hospital their favourite toys that amuse and calm them. It is obligatory autistic children to be enlisted first in the operative schedule thus the effect of waiting and hunger will be diminished; while with the ones having cognitive deficit is recommended the parents' presence. For the ASD children is typical that more frequently they tend to oppose to the anaesthesia when in their anamnesis they have similar opposition also towards other kind of manipulations, e.g. immunizations etc. [11]. That is why the usage of symbols familiar to them is very useful in pre-operative preparation; in other words communication is facilitated and their anxiety is considerably reduced. For this purpose with these children are implemented the so called widgit symbols (Figure1, Figure 2) [12]. The pictures' sequence follows the sequence of events before, during and after anaesthesia.

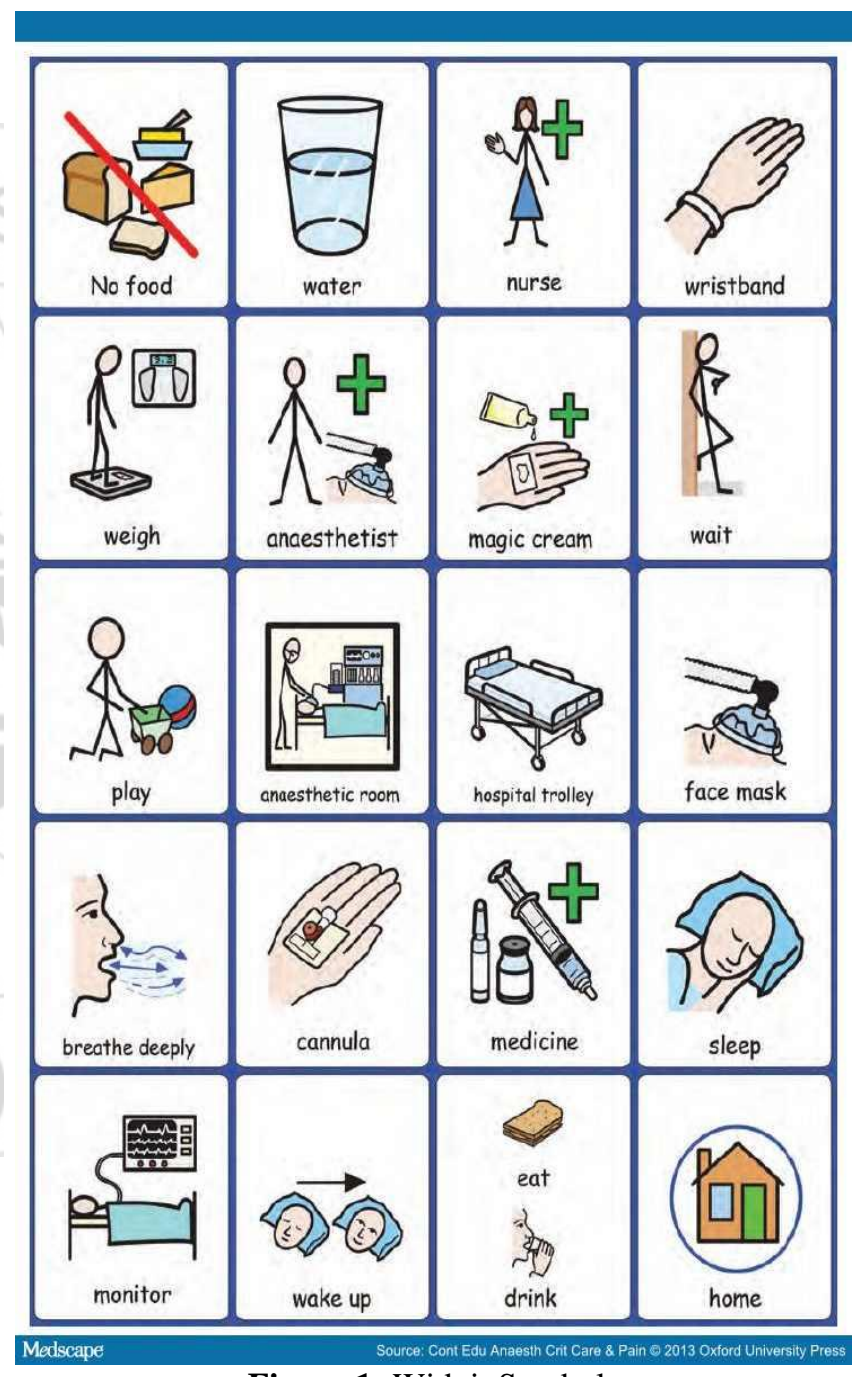

Figure 1: Widgit Symbols 


\section{International Journal of Science and Research (IJSR) \\ ISSN (Online): 2319-7064}

Index Copernicus Value (2013): 6.14 | Impact Factor (2015): 6.391

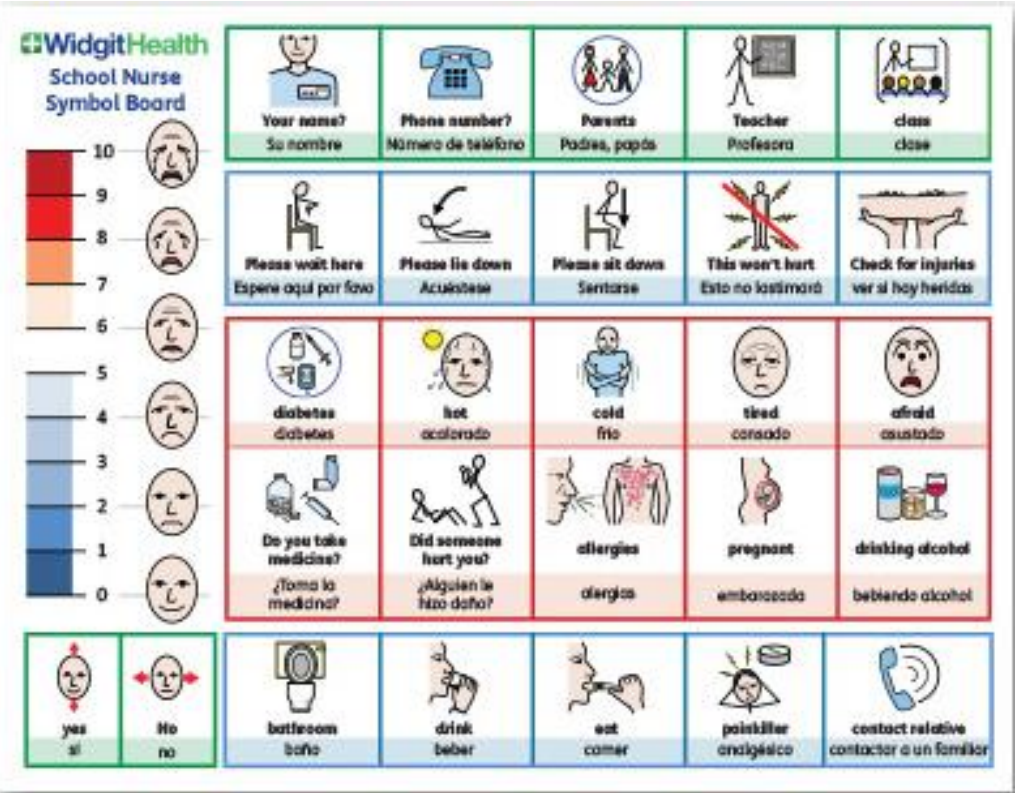

Figure 2: Widgit symbols

With children having limited speech the anaesthesiologistreanimator could make use of the sign language applying the communication system through pictures: (Figure 3) [13].

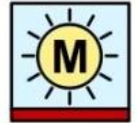

Monday

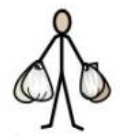

Shopping

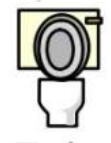

Toilet

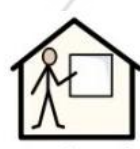

School

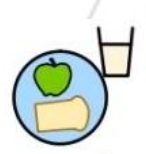

Lunch

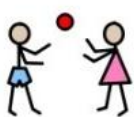

Play
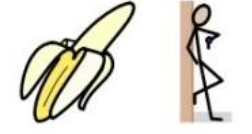

Banana Wait bog! !

More

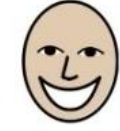

Happy
Figure 3: Implemented sign language [13]

\section{Preparation \\ for Pre-Medication Anaesthesia}

The permanent venous catheter is fixed like with the other children. The preliminary skin treatment with EMLA at the puncture point or induction with inhaling anaesthetics are proper techniques in such cases.

Premedication: Per-oral premedication is preferred [14], [15], [Table 3]. Midazolam application in doses higher than $0,5 \mathrm{mg} / \mathrm{kg}$ leads more frequently to paradoxical dysphoria. Despite this its fast beginning and short time effect, as well as the lack of side effects make it an attractive medicine in these cases [16].

Per-oral Midazolam application is considered as more effective with children having lighter degree of autism. It can be diluted in the child's favourite juice. Ketamin is another medicine that due to its sedative and analgetic qualities also finds a wide application with these children [17].

Preferred per-oral dosage $-8 \mathrm{mg} / \mathrm{kg}$.

Some authors consider its independent application in premedication as not so effective.[16](Ghai B.). It is used in moderate to severe cases of autism. Nevertheless, the combination of both medicines is preferred by most authors, in other words they neutralize mutually to a certain extend the side effects[14], [18], [19], [20].

In several studies, the successful application of alphaadrenergetic agonists is also being proved.

Per-oral application of Klonidin at dosage $2-4 \mathrm{mcg} / \mathrm{kg}$ has excellent sedative and anxiolytic effect with ASD children[14], [21]. In 1990 Dexmedetomidine was presented; it is another medicine that became popular in more than 1100 published reports dealing with its application. It is attractive for premedication, i.e. it has reliable sedative effect, it has excellent safe profile with minimal risk of defying respiratory depression and changes in haemodymanics [22].

Its per-oral application for anaesthesia induction or for sedation is effective even with patients with behavioral disorders who have had previous, unsuccessful attempts for sedation [23].

Nevertheless, due to the considerable suppression of sinus and atrioventricular nodal function with children, it is not suitable with these having bradycardia or antrioventricular block [23]. 


\section{International Journal of Science and Research (IJSR) \\ ISSN (Online): 2319-7064}

Index Copernicus Value (2013): 6.14 | Impact Factor (2015): 6.391

Table 3: Premedication in children with special needs including the ASD ones: [12].

\begin{tabular}{|c|c|c|c|c|}
\hline Medicine & Manner of application & Dosage & Maximal dosage & Start of action \\
\hline Midazolam & PO & $0.25-1 \mathrm{mg} \mathrm{kg}^{-1}$ & $20 \mathrm{mg}$ & $20-30 \mathrm{~min}$ \\
\hline Ketamin & $\mathrm{PO}$ & $3-5 \mathrm{mg} \mathrm{kg}^{-1}$ & & $30-60 \mathrm{~min}$ \\
\hline & $\mathrm{IM}$ & $1-2 \mathrm{mg} \mathrm{kg}^{-1}$ & & $\sim 3 \mathrm{~min}$ \\
\hline $\begin{array}{c}\text { Midazolam } \\
\text { Ketamin }\end{array}$ & $\mathrm{PO}$ & $0,5 \mathrm{mg} \mathrm{kg}^{-1}$ & $20 \mathrm{mg}$ & $\sim 30 \mathrm{~min}$ \\
\hline Klonidin & & $3 \mathrm{mg} \mathrm{kg}^{-1}$ & & \\
\hline Lorazepam & PO & $4 \mathrm{mkg} \mathrm{kg}^{-1}$ & $150 \mathrm{mkg}$ & $45-60 \mathrm{~min}$ \\
\hline
\end{tabular}

$\begin{array}{ll}\begin{array}{l}\text { Anaesthesia and possible complications after } \\ \text { anaesthesia: }\end{array} & \begin{array}{l}\text { 2)Serum magnesium levels; } \\ \text { 3)Differential complete blood test; } \\ \text { 4)Serum creatinine-kenase; }\end{array} \\ \begin{array}{ll}\text { Some risk factors leading to unwanted complications after } & \begin{array}{l}\text { 5)Serum amylase; } \\ \text { anaesthesia are: }\end{array} \\ \text { 6)Serum ammonium level;[24] }\end{array}\end{array}$

1)Anamnesis of convulsions

2) Pre-operative respiratory problems.

3)Poor clinical condition of child before the procedure.

4) Not diagnosed mitochondrial disease ( disorder in energy production, mitochondrial myopathy, known also as mitochondrial oxidative phosphorylation - OXPHOS ).

All these impose during the preoperative period to be tested indicators as:

1)Complete metabolic profile;

Post-operative anaesthesia: Children with special needs have to be well anaesthetized, i.e. during the post-operative period it is difficult to make difference between crying due to operative pain and due to other reasons like nausea, fear of the unfamiliar setting etc. In these cases the anaesthesiologist is assisted by the behavioral pain scales. [Table 4]

Table 4: Behavioral pain scale

Applied to patients who can not report the pain presence without outside help: estimation from 0 to 10 at clinical

\begin{tabular}{|c|c|c|c|c|}
\hline Face & $\begin{array}{c}\mathbf{0} \\
\text { Loose facial } \\
\text { muscles }\end{array}$ & $\begin{array}{c}\mathbf{1} \\
\text { Facial-muscle tension, } \\
\text { they frown and make } \\
\text { grimaces }\end{array}$ & $\begin{array}{c}2 \\
\text { Frequently or most of the } \\
\text { time are frowned, tensed } \\
\text { lower jaw }\end{array}$ & $\begin{array}{c}\text { Face } \\
\text { Result: }\end{array}$ \\
\hline Anxiety & $\begin{array}{c}\text { 0 } \\
\text { Quiet, calm } \\
\text { vision, normal } \\
\text { movement }\end{array}$ & $\begin{array}{l}\mathbf{1} \\
\text { Rarely affected nervous } \\
\text { move-ments and } \\
\text { change in body position }\end{array}$ & $\begin{array}{c}\text { 2 } \\
\text { Frequent nervous } \\
\text { movements, which can } \\
\text { include head and limbs }\end{array}$ & $\begin{array}{l}\text { Anxiety } \\
\text { Result : }\end{array}$ \\
\hline Muscle tonus* & \begin{tabular}{|c|} 
0 \\
Normal \\
muscle tone \\
\end{tabular} & $\begin{array}{l}\text { Higher tone, flexion of } \\
\text { hands and legs fingers }\end{array}$ & $\begin{array}{c}\mathbf{2} \\
\text { Rigid tone } \\
\end{array}$ & $\begin{array}{l}\text { Muscle tone } \\
\text { Result : }\end{array}$ \\
\hline Vocalization $* *$ & $\begin{array}{c}\text { 0 } \\
\text { There are NO } \\
\text { unusual } \\
\text { sounds }\end{array}$ & $\begin{array}{c}\mathbf{1} \\
\text { Casual moanings, } \\
\text { shouts, moaning and } \\
\text { groaning }\end{array}$ & $\begin{array}{c}\mathbf{2} \\
\text { Frequent or continuous } \\
\text { moans, cries, whimpers or } \\
\text { grunts }\end{array}$ & $\begin{array}{l}\text { Vocalization } \\
\text { Result : }\end{array}$ \\
\hline $\begin{array}{l}\text { Possibility to be } \\
\text { clamed down }\end{array}$ & $\begin{array}{c}\mathbf{0} \\
\text { There is } \\
\text { content, calm }\end{array}$ & $\begin{array}{c}\text { 1 } \\
\text { Children are calmed } \\
\text { when touched, can be } \\
\text { distracted }\end{array}$ & $\begin{array}{c}\mathbf{2} \\
\text { It is difficult to be } \\
\text { comforted by touching or } \\
\text { conversation }\end{array}$ & $\begin{array}{l}\text { Possibility to be } \\
\text { calmed down } \\
\text { Result : }\end{array}$ \\
\hline \multicolumn{4}{|c|}{ Behavioral scale for pain is estimated pursuant ten-grade scale $(0-10)$} & $0 / 10$ \\
\hline
\end{tabular}

* Estimation of muscle tone in patients with lesion of spinal cord or with a wound above the lesion location. It estimates patients with hemiplegia on the side that is not damaged.

** This element can not be measured in patients on artificial lung ventilation.

\section{Conclusion}

Frequently the children from autistic spectrum (ASD) are in need of medical tests, manipulations or operations that impose the implementation of sedation or anaesthesia. The nature of their disease is connected with an increased anxiety level, frequently they do not respond, sometimes they can be aggressive and this imposes necessity to have extensive knowledge of this kind of conditions.
Adequate pre-operative preparation is necessary in order the children with this disorder to receive successfully implemented anaesthesia.

This preparation requires not only the habitual for every surgical intervention consultations with pediatrician, anaesthesiologist and other specialists, but also close collaboration with psychologists who are well acquainted with the specific character of this condition. 


\section{International Journal of Science and Research (IJSR) \\ ISSN (Online): 2319-7064 \\ Index Copernicus Value (2013): 6.14 | Impact Factor (2015): 6.391}

Unfortunately, in Bulgaria there is still no team approach in the work among anaesthesiologists-reanimators and psychologists; this poses several questions for the active role of psychologist in pre- and post-operative preparation and care for these children.

\section{References}

[1] Isaksen, J., P. Holth, An operant approach to teaching joint Attention skills tochildren with autism, Behavioral Interventions, 2009, 24: 215-236.

[2] www.doctorbg.com

[3] Levterova, D. Actual problems of special education, Pd., 2002, p. 106-108/.

[4] Levterova, D. Actual problems of special education, Pd., 2002, p. 104-105/.

[5] Morales, R. Autism fear. New unique approach, S., 2009, p. 21-23/

[6] Levterova, D, p 105; E. McGuire A., R. Michalko, Minds Between Us: Autism, mindblindness and the uncertainty of communication, Educational Philosophy and Theory, Vol. 43, No. 2, 201, p. 162-177.

[7] McGuire E. A., Michalko R., Minds Between Us: Autism, mindblindness and the uncertainty of communication, Educational Philosophy and Theory, Vol. 43, No. 2, 201, p. 162-177

[8] Luis L. Special Diets for Special Kids. 2010.

[9] Dillenburger, K., M. Keenan, A. Doherty, T.Byrne St. Gallagher, Living with children diagnosed with autistic spectrum disorder: parental and professional views, British Journal of Special Education, 2010, Vol. 37, Issue 1, p. 13-23.

[10] Rainey L, van der Walt JH. The anaesthetic management of autistic children. Anaesth Intensive Care. 1998; 26: 682-686.

[11] Proczkowska-Björklund M, Svedin CG. Child related background factors affecting compliance with induction of anaesthesia.Paediatr Anaesth. 2004; 14: 225-234.

[12] Judith Alison Short. Anaesthesia for children with special needs, including autistic spectrum disorder. Continuing Education in Anaesthesia, Critical Care \& Pain Advance Access published January 29, 2013.

[13] www.pecs.org.uk

[14] Karam VY, Barakat H. Perioperative management of the child with behavioral disorders.

[15] Bozkurt P. Premedication of the pediatric patient anesthesia for the uncooperative child. Curr Opin Anaesthesiol. 2007; 20: 211-215.

[16] Ghai B, Grandhe RP, Kumar A, Chari P. Comparative evaluation of midazolam and ketamine with midazolam alone as oral premedication. Paediatr Anaesth. 2005; 15: 554-559.

[17] Filatov SM, Baer GA, Rorarius MG, Oikkonen M. Efficacy and safety of premedication with oral ketamine for day-case adenoidectomy compared with rectal diazepam/diclofenac and EMLA. Acta Anaesthesiol Scand. 2000; 44: 118-124.

[18] Christiansen E, Chambers N. Induction of anesthesia in a combative child; management and issues. Paediatr Anaesth. 2005;15: 421-425.

[19] Darlong V, Shende D, Subramanian MS, Sunder R, Naik A. Oral ketamine or midazolam or low dose combination for premedication in children. Anaesth Intensive Care. 2004; 32:246-9.

[20] Shailesh Shah, Sonia Shah, Jesus Apuya, Senthil Gopalakrishnan, Timothy Martin. Combination of oral ketamine and midazolam as a premedication for a severely autistic and combative patient. Journal of Anesthesia 2009;23:126-128

[21] Thompson DG, Tielsch-Goddard A. Improving Management of Patients With Autism Spectrum Disorder Having Scheduled Surgery:Optimizing Practice. 2013.

[22] Greenberg B. MD, Schoonover J. NP, Jedlicki K. NP, Graf A. NP, Overbey E. MD, et al (2010). Intranasal Combination Dexmedetomidine and Midazolam for Pediatric Procedural Sedation: A New and Palatable Approach. Paper Presented at SPA meeting in San Antonio.

[23] Zub D1, Berkenbosch JW, Tobias JD . Preliminary experience with oral dexmedetomidine for procedural and anesthetic premedication. Paediatr Anaesth. 2005; 15: 932-938.

[24] Alyssa Davi. Anesthesia and Sedation Risks in Children Labeled with Autistic Spectrum Disorder. P. $1-2$. 